\title{
A theoretical study for high-performance inverted p-i-n architecture perovskite solar cells with cuprous iodide as hole transport material
}

\author{
Syed Zulqarnain Haider ${ }^{1}$, Hafeez Anwar ${ }^{*}, 1$, Sehrish Manzoor ${ }^{1}$, Ahmad G. Ismail ${ }^{2}$ and Mingqing Wang ${ }^{3}$ \\ ${ }^{1}$ Department of Physics, University of Agriculture Faisalabad-38040 Pakistan \\ ${ }^{2}$ Institute of Microengineering and Nanoelectronics, National University of Malaysia \\ ${ }^{3}$ Institute for Materials Discovery, University College of London United Kingdom \\ *E-mail: hafeez.anwar@gmail.com
}

\begin{abstract}
Inverted perovskite solar cells ( $\mathrm{p}-\mathrm{i}-\mathrm{n}$ PSCs) have been fascinated due to rapid progress of performance in recent years. PEDOT: PSS is commonly used hole transport material (HTM) in p-i-n PSCs which is hygroscopic and acidic in nature that leads towards poor performance of device thus hinders commercialization of PSCs. Therefore, it is necessary to replace PEDOT: PSS with stable HTM in p-i-n PSCs. In this paper, theoretical study is carried out to investigate various physical parameters that can affect the performance of p-i-n PSCs with copper iodide (CuI) as HTM and phenyl-C61-butyric acid methyl ester (PCBM) as ETM. These parameters include the effect of doping density of ETM, absorber, and HTM as well as defect density and thickness of absorber on the performance of p-i-n PSCs. In addition, hole mobility and thickness of HTM is also investigated. It is found that performance of $\mathrm{p}-\mathrm{i}-\mathrm{n}$ PSC is strongly dependent on defect density and thickness of absorber layer while other physical parameters have minor influence on the performance of device. Upon final optimization, device attains PCE of more than $21 \%$ which is encouraging. These results show that $\mathrm{CuI}$ as HTM is a potential choice for p-i-n PSCs.
\end{abstract}

Keywords: theoretical study, p-i-n PSCs, CuI, PCBM, defect density, PEDOT: PSS 


\section{Introduction}

In 2009, $\mathrm{CH}_{3} \mathrm{NH}_{3} \mathrm{PbI}_{3}$ and $\mathrm{CH}_{3} \mathrm{NH}_{3} \mathrm{PbBr}_{3}$ were utilized as absorber materials by Miyasaka and colleagues in which PCE of more than $3 \%$ was achieved [1]. There had been much research work done to optimize the efficiency of n-i-p type PSCs [2-4]. Various types of PSCs, such as perovskite-sensitized solar cells, mesoporous structured PSCs and Planar heterojunction PSCs had been studied in previous few years $[1,5,6]$. Mesoporous $\mathrm{TiO}_{2}$ layers have the disadvantage of high temperature processing, therefore, the simplest design was planar hetero-junction structure [7-9]. In comparison with the mesoporous structured PSCs, planar PSC doesn't contain mesoporous layers, which simplifies production processes. In the meantime, planar PSCs, silicon and CIGS solar cells were also used to create tandem solar cells and device efficiency was further improved [10]. Planar PSCs have, therefore, attracted much attention in the field of photovoltaics [11]. Two types of planar PSCs are available such as normal and inverted structure. Normal PSCs with n-i-p structure are commonly comprised of $\mathrm{TiO}_{2}$ as $\mathrm{ETM}, \mathrm{CH}_{3} \mathrm{NH}_{3} \mathrm{PbI}_{3}$ as absorber, and spiroMeOTAD as HTM. However, the high manufacturing cost of spiro-MeOTAD and high temperature processing of $\mathrm{TiO}_{2}$ offer hurdles in the commercialization of PSCs. In order to overcome these drawbacks, inverted PSCs with p-i-n structure have been developed with PEDOT: PSS as HTM and PCBM as ETM, which exhibited the promising efficiencies about $18 \%$ [12]. Inverted PSCs have gained great popularity due to low temperature processing techniques $[13,14]$ and less current hysteresis $[15,16]$. PEDOT: PSS is a widely used HTM in p-i-n type PSCs due to its high work function, better film deposition, optical transparency and high conductivity[17]. But at the same time, PEDOT: PSS suffers some critical issues such as hygroscopic and acidic nature which causes degradation and reduces the stability of the device. Furthermore, Inverted structure of PSCs is desirable for future roll-to-roll production because of low temperature and simple 
manufacturing processes $[18,19]$. In order to fabricate an efficient device, degradation process in PSCs should be controlled as $\mathrm{CH}_{3} \mathrm{NH}_{3} \mathrm{PbI}_{3}$ is vulnerable to moisture and oxygen and easily degraded [20]. $\mathrm{TiO}_{2}$ is commonly used ETM in PSCs and has photocatalytic behavior thus sensitive to ultraviolet (UV) light and has the issue of photo-stability[21]. Performance is deteriorated when UV light irradiated on front transparent electrode of PSCs. UV light is absorbed in $\mathrm{TiO}_{2}$ then photo-generated holes reacts with the adsorbed $\mathrm{O}_{2}$ which creates the $\mathrm{O}_{2}$ radical that act like a deep trap [22]. On desorbing the absorbed $\mathrm{O}_{2}$, electron is generated which recombines with hole of valence band. When light is absorbed in the absorber, photo induced electrons of absorber layer either move to conduction band of $\mathrm{TiO}_{2}$ or be surrounded by the deep traps. The remaining electrons due to the desorption of $\mathrm{O}_{2}$ then recombine with the photo induced holes from absorber layer. Equations (1)-(4) represent the degradation process in absorber layer in the case of $\mathrm{CH}_{3} \mathrm{NH}_{3} \mathrm{PbI}_{3}$ when it comes in contact with moisture and $\mathrm{UV}$ light. $\mathrm{PbI}_{2}$ and $\mathrm{CH}_{3} \mathrm{NH}_{3} \mathrm{I}$ are produced as in equation (1). In equation (2), $\mathrm{CH}_{3} \mathrm{NH}_{3} \mathrm{I}$ is further decomposed to $\mathrm{CH}_{3} \mathrm{NH}_{2}$ and $\mathrm{HI}$. HI can be decomposed in two different routes. In the $1^{\text {st }}$ route (equation (3)), $I_{2}$ and water is produced when HI comes in contact with oxygen. In the $2^{\text {nd }}$ route (equation (4)), photochemical breakdown occurs and $\mathrm{HI}$ is converted into $\mathrm{I}_{2}$ and $\mathrm{H}_{2}$ due to $\mathrm{UV}$ radiation [23].

$$
\begin{gathered}
\mathrm{CH}_{3} \mathrm{NH}_{3} \mathrm{PbI}_{3} \underset{\text { moisture }}{\longrightarrow} \mathrm{PbI}_{2}+\mathrm{CH}_{3} \mathrm{NH}_{3} \mathrm{I} \\
\mathrm{CH}_{3} \mathrm{NH}_{3} \mathrm{I} \frac{\mathrm{UV}}{\text { moisture }} \mathrm{CH}_{3} \mathrm{NH}_{2}+\mathrm{HI} \\
4 \mathrm{HI}+\mathrm{O}_{2} \frac{\mathrm{UV}}{\text { moisture }} 2 \mathrm{I}_{2}+2 \mathrm{H}_{2} \mathrm{O} \\
\mathrm{HI} \underset{\text { moisture }}{\stackrel{\mathrm{Uv}}{\longrightarrow}} \mathrm{H}_{2}+\mathrm{I}_{2}
\end{gathered}
$$

Theoretical analysis is as equally important as experimental study to realize working mechanism and performance optimization of device. In terms of inorganic HTMs in Pb-based inverted PSCs, device simulation has not been performed appreciably so far. For example, $\mathrm{CH}_{3} \mathrm{NH}_{3} \mathrm{PbI}_{3-\mathrm{x}} \mathrm{Cl}_{\mathrm{x}}$ 
based inverted PSC with NiO as HTM was simulated using SCAPS and PCE was achieved more than $20 \%$ after optimization [24]. Furthermore, other device simulations of inverted PSCs were also performed with $\mathrm{NiO}$ as HTM [25-27]. In another device simulation, PSC was investigated with various HTMs including $\mathrm{CuI}$ in which only initial simulation was performed without any study of influence of physical parameters on performance of inverted PSC with CuI as HTM [28]. Therefore, it is dire need to further explore inorganic HTMs with hygroscopic as well as thermally and chemically stable nature. In this regard, CuI may be a suitable choice to be used as HTM in pi-n type PSCs. In this study, inverted PSC has been explored with CuI as HTM because of its photostable and hydrophobic, which provides the shielding to absorber from moisture and UV light [29]. In addition, high transmittance of $\mathrm{CuI}$ in the range of visible light (400 $\mathrm{nm}$ to $800 \mathrm{~nm}$ ) allows the absorbance of more incident photon flux and the generation of more charge carriers $[30,31]$. The structure $\mathrm{FTO} / \mathrm{CuI} / \mathrm{CH}_{3} \mathrm{NH}_{3} \mathrm{PbI}_{3} / \mathrm{PCBM} / \mathrm{Al}$ is used for the device modeling of proposed device. The influence of the thickness of absorber and CuI layers, the doping concentrations of CuI, absorber and PCBM layers as well as defect density of absorber and hole mobility of CuI on PSC device performance have been investigated.

\section{Simulated device architecture and computational details}

The device engineering of p-i-n type PSC is carried out with device architecture FTO / CuI / $\mathrm{CH}_{3} \mathrm{NH}_{3} \mathrm{PbI}_{3} / \mathrm{PCBM} / \mathrm{Al}$ as discussed above. The schematic structure of the device is shown in Figure 1a. FTO is used as front electrode. $\mathrm{CuI}$ is applied as $\mathrm{HTM}, \mathrm{CH}_{3} \mathrm{NH}_{3} \mathrm{PbI}_{3}$ is designated as absorber, PCBM is acted as ETM and Al is used as back metal contact. The band alignment is shown in Figure 1b. It is evident that $\mathrm{VBO}$ of $+0.3 \mathrm{eV}$ at the interface $(\mathrm{CuI} / \mathrm{absorber})$ is very critical for the transport of the holes, and the $\mathrm{CBO}$ at absorber/PCBM interface is $-0.2 \mathrm{eV}$ which is also very important for transport of photo-generated electrons. Two defect interfaces are used in 
order to analyze carrier recombination. One defect interface is $\mathrm{CH}_{3} \mathrm{NH}_{3} \mathrm{PbI}_{3} / \mathrm{PCBM}$ and the other one is $\mathrm{CuI} / \mathrm{CH}_{3} \mathrm{NH}_{3} \mathrm{PbI}_{3}$. The defect type is chosen as single with defect density of $1 \times 10^{10} \mathrm{~cm}^{-3}$. Defect parameters of interfaces and material properties of each layer are shown in Tables $\mathbf{1}$ and 2 respectively.
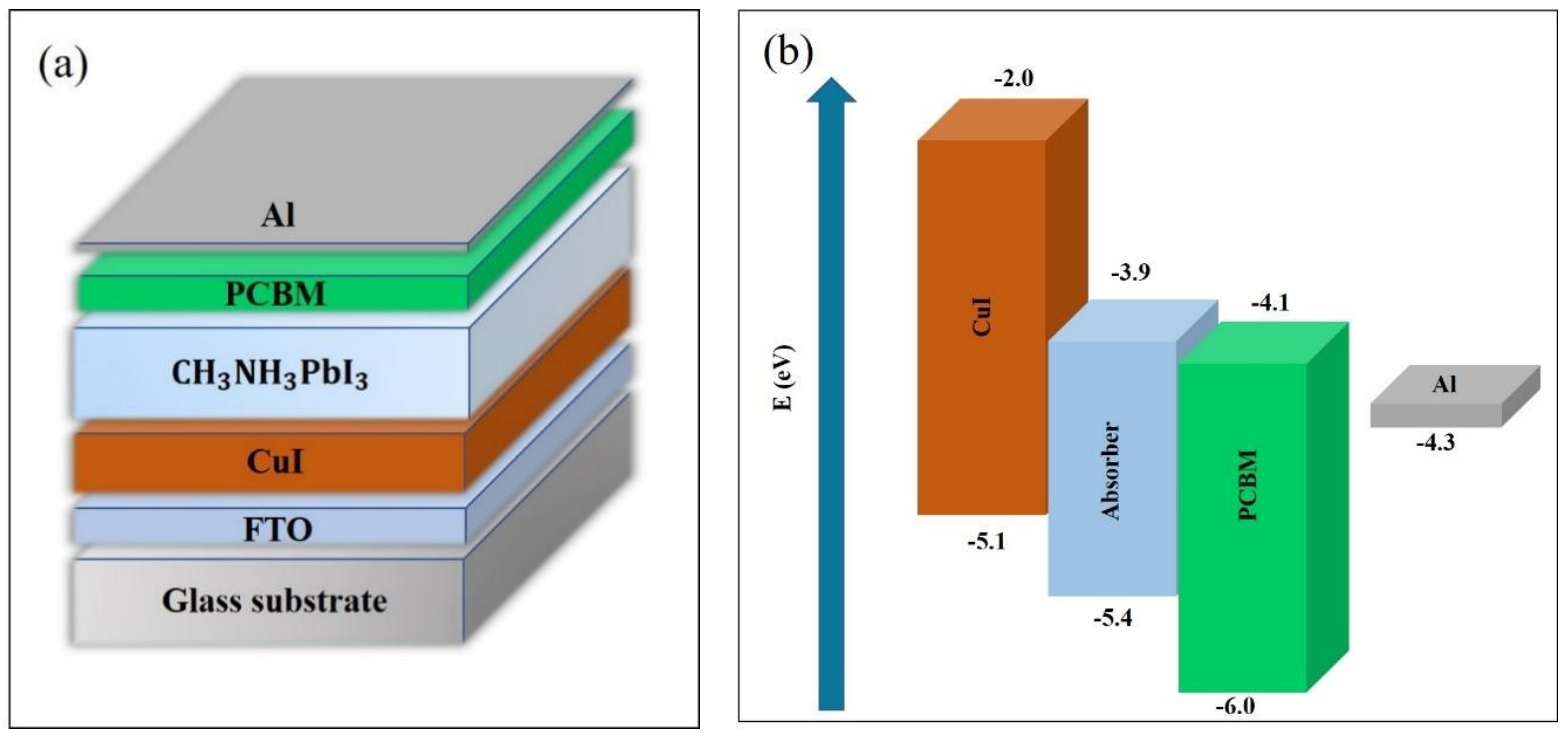

Figure 1. (a) Schematic diagram of inverted PSC with CuI as HTM (b) Band alignment diagram of inverted PSC with CuI as HTM

\begin{tabular}{lccc}
\hline \multicolumn{1}{c}{ Parameters } & $\begin{array}{c}\mathrm{CuI} / \mathrm{CH}_{3} \mathrm{NH}_{3} \mathrm{PbI}_{3} \\
\text { interface }\end{array}$ & $\mathrm{CH}_{3} \mathrm{NH}_{3} \mathrm{PbI}_{3}$ & $\begin{array}{c}\mathrm{CH}_{3} \mathrm{NH}_{3} \mathrm{PbI}_{3} / \mathrm{PCBM} \\
\text { interface }\end{array}$ \\
\hline $\begin{array}{l}\text { Defect type } \\
\text { Capture cross section } \\
\text { for holes }\left(\mathrm{cm}^{2}\right)\end{array}$ & Neutral & Neutral & Neutral \\
$\begin{array}{l}\text { Capture cross section } \\
\text { for electrons }\left(\mathrm{cm}^{2}\right)\end{array}$ & $1 \times 10^{-19}$ & $2 \times 10^{-14}$ & $1 \times 10^{-19}$ \\
$\begin{array}{l}\text { Energetic distribution } \\
\text { Energy level with }\end{array}$ & Single & $2 \times 10^{-14}$ & $1 \times 10^{-19}$ \\
$\begin{array}{l}\text { respect to E }(\mathrm{eV}) \\
\text { Characteristic energy } \\
(\mathrm{eV})\end{array}$ & 0.600 & Single & Single \\
Total density $\left(\mathrm{cm}{ }^{-3}\right)$ & 0.1 & 0.100 & 0.600 \\
\hline
\end{tabular}




\begin{tabular}{|c|c|c|c|c|}
\hline Parameters & FTO & $\begin{array}{l}\text { HTM } \\
(\mathrm{CuI})\end{array}$ & $\begin{array}{c}\text { Absorber } \\
\left(\mathrm{CH}_{3} \mathrm{NH}_{3} \mathrm{PbI}_{3}\right)\end{array}$ & $\begin{array}{c}\text { ETM } \\
(\text { PCBM })\end{array}$ \\
\hline Thickness $(\mu \mathrm{m})$ & 0.500 & 0.400 & 0.250 & 0.010 \\
\hline Relative permittivity $\varepsilon_{\mathrm{r}}$ & 9 & $6.5[32]$ & 6.5 [33] & $4[34]$ \\
\hline Hole mobility $\mu_{p}\left(\mathrm{~cm}^{2} V^{-1} \mathbf{s}^{-1}\right)$ & 8 & $1.69 \times 10^{-4}[35]$ & 10 & $2 \times 10^{-4}[36]$ \\
\hline $\begin{array}{l}\text { Acceptor concentration } \mathrm{N}_{\mathrm{A}} \\
\left(\mathrm{cm}^{-3}\right)\end{array}$ & 0 & $2 \times 10^{17}[37]$ & $1 \times 10^{17}[38]$ & 0 \\
\hline $\begin{array}{l}\text { Electron mobility } \mu_{n} \\
\left(\mathrm{~cm}^{2} \mathbf{V}^{-1} \mathbf{s}^{-1}\right)\end{array}$ & 20 & $1.69 \times 10^{-4}$ & 10 [39] & $2 \times 10^{-3}$ \\
\hline $\begin{array}{l}\text { Donor concentration } N_{D} \\
\left(\mathrm{~cm}^{-3}\right)\end{array}$ & $2.0 \times 10^{19}$ & 0 & 0 & $1 \times 10^{16}[40]$ \\
\hline $\begin{array}{l}\text { Effective valance band } \\
\text { density } N_{v}\left(\mathrm{~cm}^{-3}\right)\end{array}$ & $1.8 \times 10^{19}$ & $1.0 \times 10^{19}[41]$ & $1.8 \times 10^{19}[42]$ & $\begin{array}{c}1.0 \times 10^{19} \\
{[43]}\end{array}$ \\
\hline Band gap energy $E_{g}(e V)$ & 3.5 & $3.1[44]$ & $1.50[45]$ & $1.9[46]$ \\
\hline Defect density $N_{t}\left(\mathrm{~cm}^{-3}\right)$ & $1 \times 10^{15}$ & $1 \times 10^{16}$ & $1 \times 10^{16}$ & $1 \times 10^{14}$ \\
\hline $\begin{array}{l}\text { Effective conduction band } \\
\text { density } N_{c}\left(\mathrm{~cm}^{-3}\right)\end{array}$ & $2.0 \times 10^{18}$ & $2.8 \times 10^{19}[41]$ & $2.2 \times 10^{18}[42]$ & $\begin{array}{c}1.5 \times 10^{18} \\
{[47]}\end{array}$ \\
\hline Electron affinity $\chi(\mathrm{eV})$ & 4 & $2.1[48]$ & $3.9[49]$ & $3.9[50]$ \\
\hline
\end{tabular}

Table 1. Defect parameters of interfaces and absorber of p-i-n type PSC with CuI as HTM

Table 2. Simulation parameters of inverted PSC with CuI as HTM.

\section{Results and discussion}

The J-V curve has been drawn with the physical parameters given in tables $\mathbf{1}$ and $\mathbf{2}$ as shown in curve (a) of Figure 2a. $\mathrm{J}_{\mathrm{sc}}$ of $18.29 \mathrm{~mA} / \mathrm{cm}^{2}$, Voc of $1.05 \mathrm{~V}$, FF of $65.33 \%$, and PCE of $12.56 \%$ are obtained. The simulated device performance and experimental results are consistent for inverted $\mathrm{Pb}$-based PSCs [51]. CuI layer is highly transparent in the visible range from $400-$ $800 \mathrm{~nm}$ and this high transparency makes CuI more suitable as HTM in inverted PSC so that more photons can reach absorber to generate charge carriers [52]. From Figure 2b, optical absorption edge and maximum absorbance lie at $850 \mathrm{~nm}$ and $400 \mathrm{~nm}$ respectively in quantum efficiency (QE) 
curve covering visible spectrum which is in agreement with experimental work [16]. This agreement validates that input simulation parameters are close to the real device.
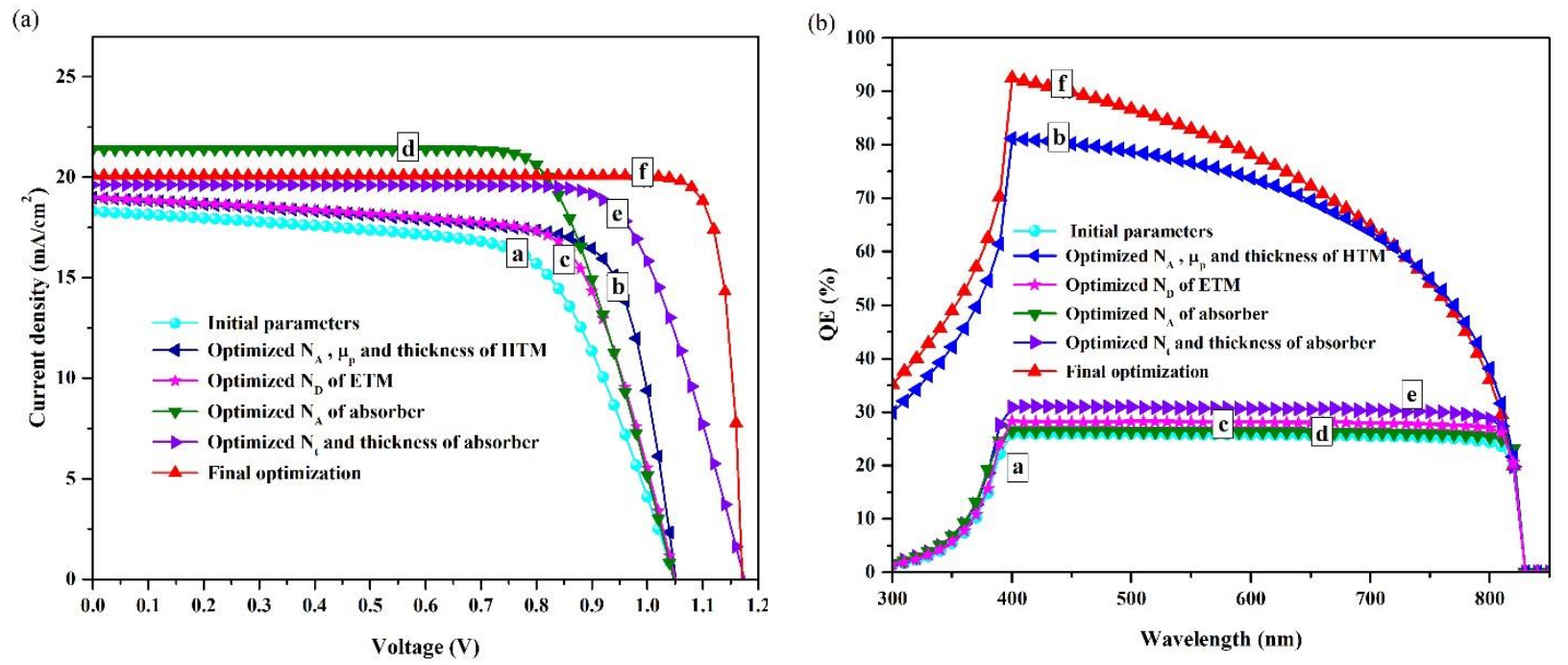

Figure 2. Simulated optimized (a) J-V (b) QE characteristics of inverted PSC

\subsection{Influence of doping density $\left(\mathrm{N}_{\mathrm{A}}\right)$, hole mobility $\left(\mu_{\mathrm{p}}\right)$ and thickness of $\mathrm{CuI}$ layer}

$\mathrm{N}_{\mathrm{A}}$ of $\mathrm{CuI}$ is directly related to the recombination rate and energy bands. Therefore, performance of PSCs is considerably influenced by $\mathrm{N}_{\mathrm{A}} . \mathrm{J}_{\mathrm{sc}}$ is almost constant when $\mathrm{N}_{\mathrm{A}}$ of $\mathrm{CuI}$ is smaller than $1 \times 10^{15} \mathrm{~cm}^{-3}$. But, $\mathrm{J}_{\mathrm{sc}}$ increases when $\mathrm{N}_{\mathrm{A}}$ of $\mathrm{CuI}$ increases from $1 \times 10^{15} \mathrm{~cm}^{-3}$ to $1 \times 10^{18} \mathrm{~cm}^{-3}$ and becomes almost constant beyond $1 \times 10^{18} \mathrm{~cm}^{-3}$ as shown in Figure 3a. $\mathrm{V}_{\mathrm{oc}}$ is observed to be decreasing when $\mathrm{N}_{\mathrm{A}}$ is smaller than $1 \times 10^{14} \mathrm{~cm}^{-3}$ and shows saturated behavior with increasing $\mathrm{N}_{\mathrm{A}}$ from $1 \times 10^{14} \mathrm{~cm}^{-3}$ to $1 \times 10^{20} \mathrm{~cm}^{-3}$ as shown in Figure 3a. FF is observed to be increasing slowly with the increasing $\mathrm{N}_{\mathrm{A}}$ up to $1 \times 10^{16} \mathrm{~cm}^{-3}$ then increases rapidly up to $1 \times 10^{20} \mathrm{~cm}^{-3}$. Similarly, PCE also exhibits the same trend with increasing $\mathrm{N}_{\mathrm{A}}$ as shown in Figure 3a. Figure 3b shows that total recombination of charge carriers sharply decreases when $\mathrm{N}_{\mathrm{A}}$ increases from $1 \times 10^{15} \mathrm{~cm}^{-3}$ to $1 \times 10^{17} \mathrm{~cm}^{-3}$ which justifies the sharp increase in $\mathrm{J}_{\mathrm{sc}}$. Equation (5) can be used to express $\mathrm{V}_{\mathrm{oc}}$. 


$$
\mathrm{V}_{\mathrm{oc}}=\frac{\mathrm{k}_{\mathrm{B}} \mathrm{T}}{\mathrm{e}} \ln \left(\frac{\mathrm{I}_{\mathrm{ph}}}{\mathrm{I}_{\mathrm{s}}}+1\right)
$$

Where $I_{p h}$ is photocurrent and $I_{s}$ is reverse saturation current. It is shown in Figure 5 that height of the potential barrier increases with the increase of $N_{A}$ which results in the decrease of $I_{s}$. Therefore, $\mathrm{V}_{\mathrm{oc}}$ increases with the increase of $\mathrm{N}_{\mathrm{A}}$ which is also justified by equation (5) and peak value of $\mathrm{V}_{\mathrm{oc}}$ is obtained $(1.05 \mathrm{~V})$ which is exhibited by the plateau in the Figure 3a. Finally, it can be seen that $\mathrm{N}_{\mathrm{A}}$ has optimized value of $1 \times 10^{19} \mathrm{~cm}^{-3} \cdot \mu_{\mathrm{p}}$ is the measurement of transport of holes when external electric field is applied. $\mathrm{N}_{\mathrm{A}}$ also affects the $\mu_{\mathrm{p}}$ of HTM defines its limits the $\mu_{\mathrm{p}}$ due to impurity scattering and lattice scattering respectively.
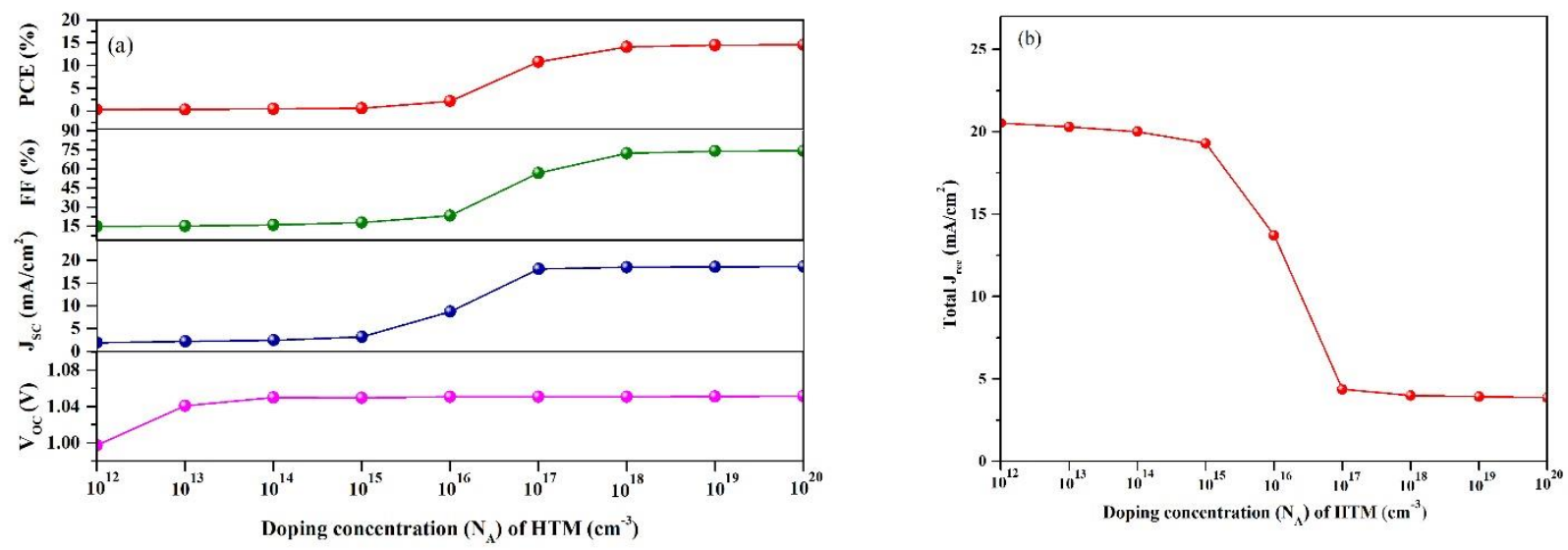

Figure 3. Performance variations of inverted PSC with (a) increasing $\mathrm{N}_{\mathrm{A}}$ of HTM (b) total recombination current with the $\mathrm{N}_{\mathrm{A}}$ of HTM

The influence of $\mu_{\mathrm{p}}$ of $\mathrm{CuI}$ has been analyzed on the performance of proposed inverted PSC. $\mathrm{J}_{\mathrm{sc}}$ and PCE increases with the increase of $\mu_{\mathrm{p}}$ of HTM which leads towards the improved charge extraction and charge transport at HTM / absorber interface as shown in Figure 4a. FF also increases with the increase of $\mu_{\mathrm{p}}$ while $V_{\mathrm{oc}}$ remains almost constant. The optimized $\mu_{\mathrm{p}}$ is found to be $1 \times 10^{-2} \mathrm{~cm}^{2} \mathrm{~V}^{-1} \mathrm{~s}^{-1}$. Furthermore, thickness of CuI as HTM has vital role on the performance of device as generation and recombination rate are affected by the variation in thickness of CuI in 
PSC. It is shown from Figure $4 \mathbf{b}$ that $\mathbf{J}_{\mathrm{sc}}$ increases when thickness of $\mathrm{CuI}$ increases from $0.01 \mu \mathrm{m}$ to $0.1 \mu \mathrm{m}$ and then decreases with the increasing thickness of $\mathrm{CuI}$ onwards. $\mathrm{V}_{\mathrm{oc}}$ remains unaffected with the increasing thickness of $\mathrm{CuI}$ which indicates that resistivity increases with the increasing thickness of CuI.
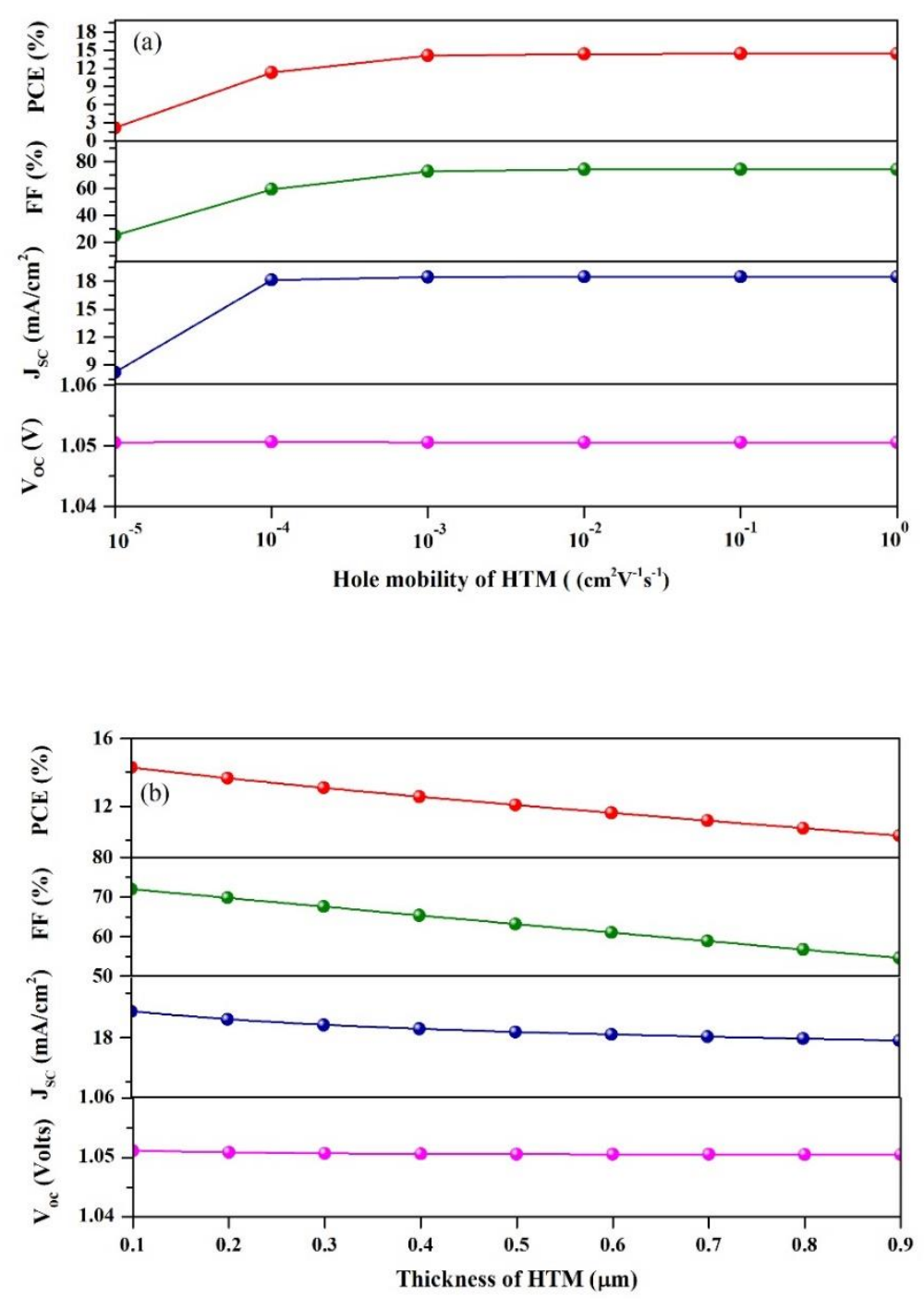

Figure 4. Performance variations of inverted PSC with (a) increasing $\mu_{\mathrm{p}}$ (b) increasing thickness of HTM 
The best FF is $73 \%$ which is obtained when thickness is $0.1 \mu \mathrm{m}$ and poor FF is $58 \%$ which is obtained when thickness is $0.9 \mu \mathrm{m}$. At the end, optimum performance with $\mathrm{J}_{\mathrm{sc}}$ of $18.97 \mathrm{~mA} / \mathrm{cm}^{2}$, PCE of $14.81 \%$, FF of $74.26 \%$ and $\mathrm{V}_{\mathrm{oc}}$ of $1.05 \mathrm{~V}$ is obtained under the optimized $\mathrm{N}_{\mathrm{A}}$ of $1 \times 10^{19} \mathrm{~cm}^{-3}, \mu_{\mathrm{p}}$ of $1 \times 10^{-2} \mathrm{~cm}^{2} \mathrm{~V}^{-1} \mathrm{~s}^{-1}$ and thickness of $0.1 \mu \mathrm{m}(100 \mathrm{~nm})$. The optimized J-V curve and QE curve are shown in curve (b) of Figure 2(a-b).

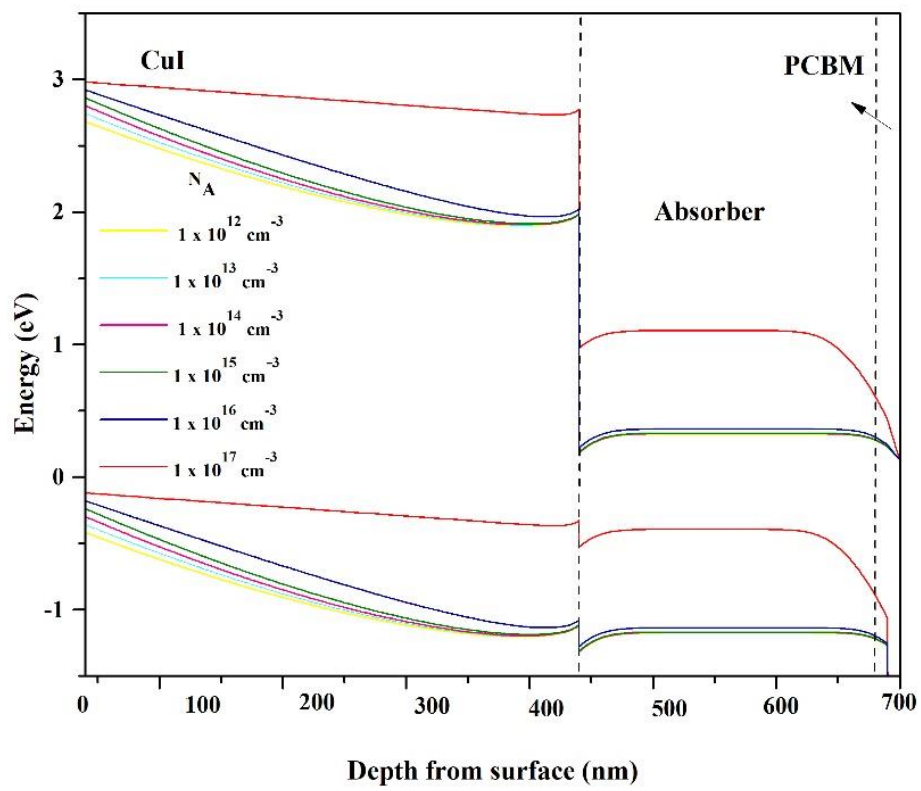

Figure 5. Energy band diagram of inverted PSC with various $\mathrm{N}_{\mathrm{A}}$ values of $\mathrm{CuI}$

\subsection{Influence of doping density $\left(\mathrm{N}_{\mathrm{D}}\right)$ of PCBM layer}

The influence of $\mathrm{N}_{D}$ of PCBM will be discussed in this section. PCBM is used as ETM in PSC because it has well matched highest occupied molecular orbital (HOMO) and lowest unoccupied molecular orbital (LUMO) with $\mathrm{CB}$ and VB of absorber which facilitates the better electron transport to PCBM. At the absorber / PCBM interface, transport of holes is ceased due to low lying HOMO of PCBM as compared to $\mathrm{CB}$ of absorber [53]. From Figure $\mathbf{6 a}, \mathbf{J}_{\mathrm{sc}}$ is almost constant with the increasing $\mathrm{N}_{D}$ of PCBM. This is due to the fact that net generation rate of charge carriers is also constant with the increasing $\mathrm{N}_{D}$ of PCBM (Figure 6b). $\mathrm{V}_{\mathrm{oc}}$ increases when $\mathrm{N}_{\mathrm{D}}$ of PCBM 
increases from $1 \times 10^{13} \mathrm{~cm}^{-3}$ to $1 \times 10^{15} \mathrm{~cm}^{-3}$ and saturates to $1.05 \mathrm{~V}$ when $\mathrm{N}_{\mathrm{D}}$ exceeds $1 \times 10^{15} \mathrm{~cm}^{-3}$ as shown in Figure 6a. Since height of potential barrier increases with the increasing of $\mathrm{N}_{\mathrm{D}}$ of PCBM, which results in the decrease of $\mathrm{I}_{\mathrm{s}}$. Therefore, $\mathrm{V}_{\mathrm{oc}}$ increases with the increase of $\mathrm{N}_{\mathrm{D}}$ evident from equation (5).
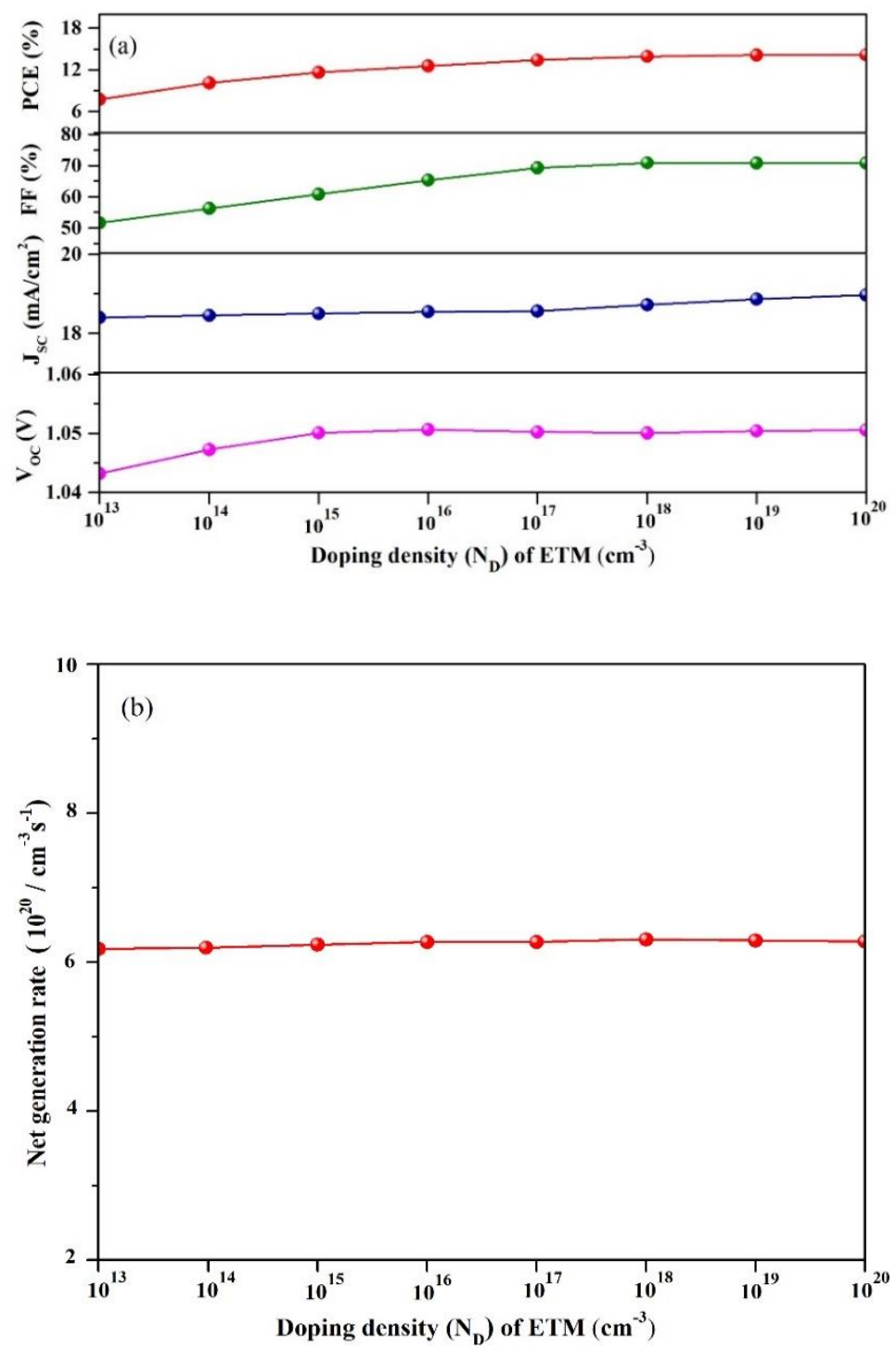

Figure 6. (a) Performance variations of inverted PSC (b) net generation rate of inverted PSC with increasing $\mathrm{N}_{D}$ of ETM 
It is also evident that fall in $\mathrm{I}_{\mathrm{s}}$ becomes slow when $\mathrm{N}_{\mathrm{D}}$ exceeds $1 \times 10^{15} \mathrm{~cm}^{-3}$ leads towards saturated $\mathrm{V}_{\mathrm{oc}}$ FF increases when $\mathrm{N}_{\mathrm{D}}$ of PCBM increases from $1 \times 10^{10} \mathrm{~cm}^{-3}$ to $1 \times 10^{18} \mathrm{~cm}^{-3}$ and then saturates to $70.8 \%$ upon exceeding the value of $\mathrm{N}_{\mathrm{D}}$ from $1 \times 10^{18} \mathrm{~cm}^{-3}$. This leads towards the decrease in resistivity with the increasing $\mathrm{N}_{D}$ of PCBM shown in Figure 6a.

PCE increases when $\mathrm{N}_{\mathrm{D}}$ of PCBM increases from $1 \times 10^{13} \mathrm{~cm}^{-3}$ to $1 \times 10^{18} \mathrm{~cm}^{-3}$ and saturates to $14.1 \%$ upon exceeding the value of $\mathrm{N}_{\mathrm{D}}$ from $1 \times 10^{18} \mathrm{~cm}^{-3}$ as shown in Figure 6a. Finally, optimized performance with $\mathrm{J}_{\mathrm{sc}}$ of $19.01 \mathrm{~mA} / \mathrm{cm}^{2}$, PCE of $14.01 \%$, FF of $70.80 \%$ and $\mathrm{V}_{\text {oc }}$ of $1.05 \mathrm{~V}$ is obtained under the optimized $\mathrm{N}_{\mathrm{D}}$ of $1 \times 10^{19} \mathrm{~cm}^{-3}$ of PCBM. The curve (c) of Figure 2(a-b) represents optimized J-V curve and QE curve with optimized $\mathrm{N}_{D}$ of ETM. 


\subsection{Influence of $\mathrm{N}_{\mathrm{A}}$ of absorber}

Doping in absorber layer can enhance the performance of PSCs. Doping (n-type or p-type) depends on nature of dopants. The absorber layer in PSCs can be doped by self-doping process. Majority charge carrier type, carrier transport and density can be manipulated by n-type or p-type self-doping process in absorber layer. Lead iodide $\left(\mathrm{PbI}_{2}\right)$ and methyl ammonium iodide (MAI) are inorganic and organic precursors respectively used in the formation of absorber $\left(\mathrm{CH}_{3} \mathrm{NH}_{3} \mathrm{PbI}_{3}\right)$ layer. Furthermore, doping of absorber depends on the precursor ratio (MAI / $\mathrm{PbI}_{2}$ ) [54]. On thermal annealing, MAI rich absorber is p-doped while MAI deficit absorber is n-doped [55].

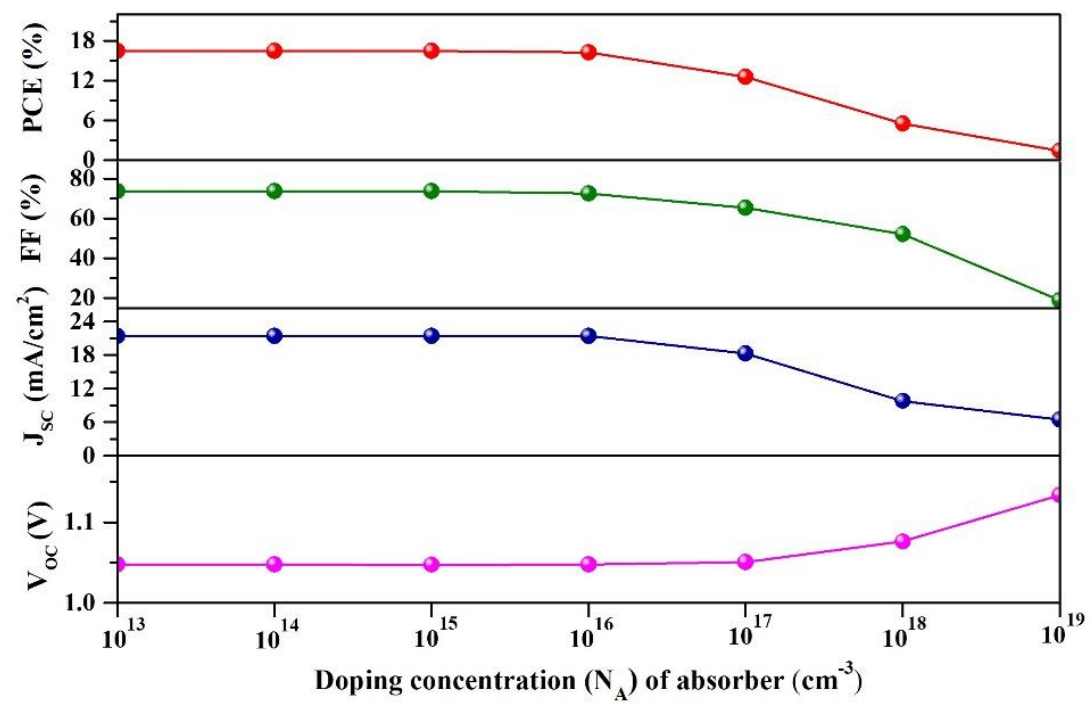

Figure 7. Performance variations of inverted PSC with increasing $\mathrm{N}_{\mathrm{A}}$ of absorber

Figure 7 shows the variation in PCE with increasing $\mathrm{N}_{\mathrm{A}}$ of absorber. When $\mathrm{N}_{\mathrm{A}}$ is $1 \times 10^{15} \mathrm{~cm}^{-3}$ then PCE is maximum and $\mathrm{J}_{\mathrm{sc}}$ also has the same trend, which shows the better transport and collection of charge carriers across absorber layer. Thus, performance of PSCs can be improved by proper selection of $\mathrm{N}_{\mathrm{A}}$ of absorber. When $\mathrm{N}_{\mathrm{A}}$ increases beyond $1 \times 10^{15} \mathrm{~cm}^{-3}, \mathrm{~J}_{\mathrm{sc}}$ begins to decrease. The internal electrical field is strengthened with the increasing $\mathrm{N}_{\mathrm{A}}$ which has very critical role in the performance variation of PSCs. Auger recombination increases with the increasing $\mathrm{N}_{\mathrm{A}}$ which is 
responsible for the decrease in $\mathrm{J}_{\mathrm{sc}}$. The hole transport is also suppressed by various scattering and recombination processes caused by increasing $\mathrm{N}_{\mathrm{A}}$ [56]. Therefore, PCE of PSC is increased by enhancing the $\mathrm{V}_{\mathrm{oc}}$ and $\mathrm{J}_{\mathrm{sc}}$ with optimum $\mathrm{N}_{\mathrm{A}}$ but recombination and scattering processes become prominent with further increase in $\mathrm{N}_{\mathrm{A}}$. Moreover, charge carrier mobility within absorber can be increased at low concentration of charge carriers. The performance is optimized with $\mathrm{V}_{\mathrm{oc}}$ of 1.05 $\mathrm{V}, \mathrm{J}_{\mathrm{sc}}$ of $21.4 \mathrm{~mA} / \mathrm{cm}^{2}$, FF of $73.6 \%$ and PCE of $16.4 \%$ when $\mathrm{N}_{\mathrm{A}}$ is $1 \times 10^{15} \mathrm{~cm}^{-3}$. The comparison between initial and optimized J-V and QE curves are shown in curve (a) and (d) of Figure 2(a-b) respectively.

\subsection{Influence of $\mathrm{N}_{t}$ and thickness of absorber}

Nt is another important absorber's parameter that needs to be discussed. The quality and morphology of absorber layer significantly changes the device performance[57]. Photoelectrons are generated when light is absorbed in the absorber layer. Poor quality of absorber layer leads towards poor coverage of PCBM layer by lead perovskite $[58,59]$. Recombination rates in absorber layer become dominant when $\mathrm{N}_{\mathrm{t}}$ increases leading towards poor quality of film. Diffusion length is the average distance travelled by charge carriers before recombination. Shockley-Read-Hall recombination is the major phenomenon in order to calculate the recombination rate of charge carriers as mentioned in equations (6) - (9).

$$
\mathrm{R}^{\mathrm{SRH}}=\frac{\mathrm{n} \cdot \mathrm{p}-\mathrm{n}_{\mathrm{i}}^{2}}{\tau_{\mathrm{p}} \cdot\left(\mathrm{n}_{\mathrm{o}}+\mathrm{n}^{\prime}\right)+\tau_{\mathrm{n}} \cdot\left(\mathrm{p}_{\mathrm{o}}+\mathrm{p}^{\prime}\right)}
$$

$\mathrm{n}_{\mathrm{o}}$ and $\mathrm{p}_{\mathrm{o}}$ show the electron and hole concentrations at equlibrium respectively while $\mathrm{n}^{\prime}$ and $\mathrm{p}^{\prime}$

shows elecron and hole concentrations in trap defects and valence band respectively. These are espressed as

$$
\mathrm{n}^{\prime}=\mathrm{N}_{\mathrm{c}} \cdot \exp \left(\frac{-\left(\mathrm{E}_{\mathrm{c}}-\mathrm{E}_{\mathrm{T}}\right)}{\mathrm{k}_{\mathrm{B}} \cdot \mathrm{T}_{\mathrm{L}}}\right)
$$




$$
\mathrm{p}^{\prime}=\mathrm{N}_{\mathrm{v}} \cdot \exp \left(\frac{-\left(\mathrm{E}_{\mathrm{T}}-\mathrm{E}_{\mathrm{v}}\right)}{\mathrm{k}_{\mathrm{B}} \cdot \mathrm{T}_{\mathrm{L}}}\right)
$$

$\mathrm{n}_{\mathrm{i}}$ is the intrinsic carrier concentration while $T_{\mathrm{L}}$ is lattice temperature and $\mathrm{E}_{\mathrm{T}}$ is the energy level of trap defect. $\mathrm{k}_{\mathrm{B}}$ is Boltzmann constant.

$$
n_{i}^{2}=n_{o} p_{o}=n^{\prime} p^{\prime}=N_{c} N_{v} \exp \left(\frac{-E_{g}}{k_{B} \cdot T_{L}}\right)
$$

when $\mathrm{E}_{\mathrm{g}}(\mathrm{eV}) \gg>3 \mathrm{k}_{\mathrm{B}} \mathrm{T}_{\mathrm{L}}$ then thermally generated $\mathrm{n}_{\mathrm{i}}^{2}$ can be neglected.

In addition to above equations, equations (10) - (12) are used to calculate electron and hole diffusion lengths $\left(L_{n}\right.$ and $\left.L_{p}\right) . \tau_{n, p}$ is carrier life time which can be given as .

$$
\tau_{\mathrm{n}, \mathrm{p}}=\frac{1}{\sigma_{\mathrm{n}, \mathrm{p}} \mathrm{v}_{\mathrm{th}} \mathrm{N}_{\mathrm{t}}}
$$

$\mathrm{V}_{\text {th }}$ represents thermal velocity and is equal to $10^{+7} \mathrm{~cm} / \mathrm{s}$ while $\sigma_{\mathrm{n}, \mathrm{p}}$ represents capture crosssection of charge carriers and $\mathrm{N}_{\mathrm{t}}$ is the density of trap defect. Diffusion coefficient (D) is given by

$$
\mathrm{D}=\frac{\mu \mathrm{k}_{\mathrm{B}} \mathrm{T}}{\mathrm{q}}
$$

$\mu$ is the carrier mobility, T and q signifies temperature (kelvin) and charge magnitude respectively.

Diffusion length (L) is given as

$$
\mathrm{L}=\sqrt{\mathrm{D} \tau}
$$

The validity of simulation is affected very little by ignoring the difference between electron and hole diffusion length. The initial value of $\mathrm{N}_{\mathrm{t}}$ is set to be $1 \times 10^{16} \mathrm{~cm}^{-3}$ in absorber. When $\mathrm{N}_{\mathrm{t}}$ increases in absorber layer then performance of PSC is deteriorated as shown in Figure 8b. The effect of $\mathrm{N}_{t}$ on device performance is analysed by considering the diffusion length of charge 
carriers which in turn depends on the SRH recombination rate and diffusion length formula. Diffusion length is changed from $113.7 \mu \mathrm{m}$ to $0.4 \mu \mathrm{m}$ by changing $\mathrm{N}_{\mathrm{t}}$ from $1 \times 10^{14}$ to $1 \times 10^{19} \mathrm{~cm}^{-3}$ respectively as shown in Table 3. The strong impact of $\mathrm{N}_{\mathrm{t}}$ is observed on FF which is an important parameter affecting the efficiency of PSCs. FF is as low as $\sim 42 \%$ at $\mathrm{N}_{\mathrm{t}}$ of $1 \times 10^{19} \mathrm{~cm}^{-3}$ and saturates to $\sim 74 \%$ for $\mathrm{N}_{\mathrm{t}}$ smaller than $1 \times 10^{14} \mathrm{~cm}^{-3} . \mathrm{V}_{\mathrm{oc}}$ and $\mathrm{J}_{\mathrm{sc}}$ also saturate to $1.17 \mathrm{~V}$ and $21.38 \mathrm{~mA} / \mathrm{cm}^{2}$ for $\mathrm{N}_{\mathrm{t}}$ smaller than $1 \times 10^{15} \mathrm{~cm}^{-3}$. FF is the most sensitive to $\mathrm{N}_{\mathrm{t}}$ among all the performance parameters of PSCs. Performance of PSCs is affected by another critical parameter which is thickness of absorber layer. Figure 8a shows the influence of absorber thickness on the device performance. Thin layer of absorber leads towards poor absorption of light causing low PCE. When absorber thickness increases, PCE increases as well which yields peak value at thickness of $200 \mathrm{~nm}$. When absorber's thickness is increased beyond $200 \mathrm{~nm}$ then recombination rate of photogenerated charge carriers increases causing low performance. The optimum performance with $\mathrm{V}_{\mathrm{oc}}$ of $1.17 \mathrm{~V}, \mathrm{~J}_{\mathrm{sc}}$ of $17.61 \mathrm{~mA} / \mathrm{cm}^{2}$, FF of $75.35 \%$ and PCE of 17.37 $\%$ is achieved with $\mathrm{N}_{\mathrm{t}}$ of $1 \times 10^{14} \mathrm{~cm}^{-3}$ and thickness of $200 \mathrm{~nm}$ of absorber layer. The optimized $\mathrm{J}-\mathrm{V}$ and QE curves are shown in curve (e) of Figure 2(a-b).

Table 3. Diffusion length of carriers in absorber layer with corresponding $\mathrm{N}_{t}$

\begin{tabular}{lcccccc}
\hline $\mathrm{N}_{\mathrm{t}}\left(\mathrm{cm}^{-3}\right)$ & $1 \times 10^{14}$ & $1 \times 10^{15}$ & $1 \times 10^{16}$ & $1 \times 10^{17}$ & $1 \times 10^{18}$ & $1 \times 10^{19}$ \\
\hline Diffusion length $(\mu \mathrm{m})$ & 113.7 & 35.9 & 11.4 & 3.6 & 1.1 & 0.4 \\
\hline
\end{tabular}



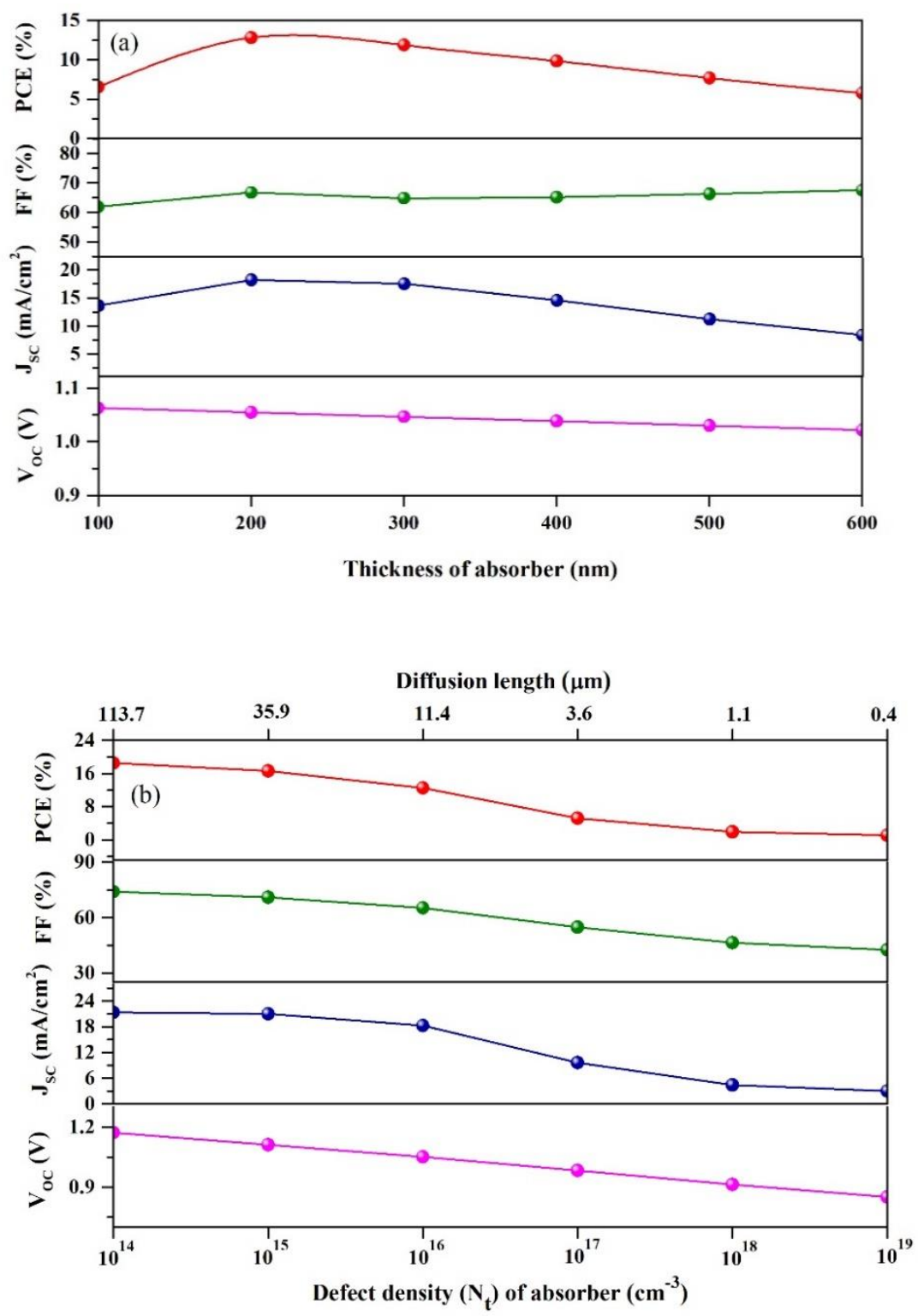

Figure 8. Performance variations of inverted PSC with increasing (a) thickness (b) $N_{t}$ of absorber

Finally, performance parameters such as $\mathrm{V}_{\mathrm{oc}}$ of $1.17 \mathrm{~V}, \mathrm{~J}_{\mathrm{sc}}$ of $20.08 \mathrm{~mA} / \mathrm{cm}^{2}$, PCE of $21.06 \%$ and FF of $89.45 \%$ are obtained on optimizing the physical parameters given in Table 4. These results are very encouraging as in previously available literature so far, best PCE of $18.4 \%$ for inverted PSC with CuI as HTM was achieved. Final optimised J-V curve is shown in curve (f) of Figure 2a. Table 5 shows the comparison between our simulated results and previously reported 
experimental results which also exhibited that better simulation results are achieved on the device modeling of inverted PSC. In the literature, $\mathrm{J}_{\mathrm{sc}}$ of $22.6 \mathrm{~mA} / \mathrm{cm}^{2}$ was reported to be higher than $\mathrm{J}_{\mathrm{sc}}$ through our simulation but $\mathrm{V}_{\mathrm{oc}}$ and FF are still needed to improve for achieving PCE upto $21.06 \%$.

Table 4. Optimized parameters of the inverted PSC with CuI as HTM

\begin{tabular}{lccc}
\hline Optimized parameters & $\mathrm{HTM}(\mathrm{CuI})$ & Absorber $\left(\mathrm{CH}_{3} \mathrm{NH}_{3} \mathrm{PbI}_{3}\right)$ & ETM $(\mathrm{PCBM})$ \\
\hline Doping density $\left(\mathrm{cm}^{-3}\right)$ & $1 \times 10^{19}$ & $1 \times 10^{15}$ & $1 \times 10^{19}$ \\
Defect density $\left(\mathrm{cm}^{-3}\right)$ & - & $1 \times 10^{14}$ & - \\
Thickness $(\mathrm{nm})$ & 100 & 200 & - \\
Hole mobility $\left(\mathrm{cm}^{2} \mathrm{~V}^{-1} \mathrm{~s}^{-1}\right)$ & $1 \times 10^{-2}$ & - & - \\
\hline
\end{tabular}

Table 5. Performance parameters of inverted PSCs with CuI as HTM for simulated results as well as experimental work reported in the literature.

\begin{tabular}{|c|c|c|c|c|c|c|c|c|c|c|c|}
\hline Parameters & \multicolumn{6}{|c|}{ Our simulation results } & \multicolumn{5}{|c|}{ Experimental results } \\
\hline & 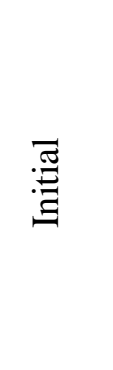 & 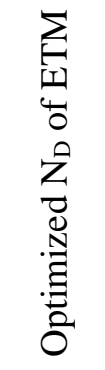 & 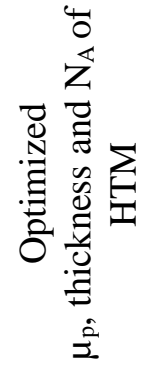 & 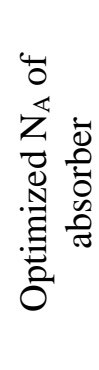 & 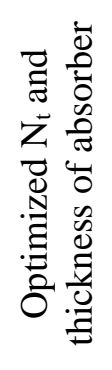 & 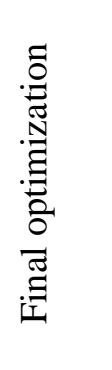 & $\bar{n}$ & $\sqrt{n}$ & 8 & $\bar{\sigma}$ & $\widetilde{\widetilde{V}}$ \\
\hline PCE $(\%)$ & 12.56 & 14.10 & 14.81 & 16.4 & 17.37 & 21.06 & 12.0 & 13.58 & 14.53 & 16.8 & 18.4 \\
\hline $\mathrm{FF}(\%)$ & 65.33 & 70.80 & 74.26 & 73.6 & 75.35 & 89.45 & 65.0 & 62 & 69 & 71.3 & 80.2 \\
\hline $\mathrm{J}_{\mathrm{sc}}\left(\mathrm{mA} / \mathrm{cm}^{2}\right)$ & 18.29 & 19.01 & 18.97 & 21.4 & 19.61 & 20.08 & 17.3 & 21.06 & 20.05 & 22.6 & 22.5 \\
\hline $\mathrm{V}_{\mathrm{oc}}(\mathrm{V})$ & 1.05 & 1.05 & 1.05 & 1.05 & 1.17 & 1.17 & 1.03 & 1.04 & 1.05 & 0.99 & 1.02 \\
\hline
\end{tabular}

This may be achieved by the improvement of crystalline quality and film morphology of absorber and HTM layer. Doped absorber and CuI could further improve the layer and interface quality by replacement of either a part of I or $\mathrm{Cu}$ by another element. 


\section{Conclusion}

In this work, theoretical study of p-i-n PSC is carried out in order to find substitute HTM for PEDOT: PSS which is hygroscopic and acidic in nature causing the degradation of the device. Various factors affecting the performance of the device were investigated. These factors include doping density of CuI, PCBM and absorber, along with hole mobility and thickness of CuI, as well as defect density and thickness of absorber. Based on device modeling results, PCE of $16.49 \%$, $\mathrm{J}_{\mathrm{sc}}$ of $21.43 \mathrm{~mA} / \mathrm{cm}^{2}$, FF of $73.6 \%$ and $\mathrm{V}_{\mathrm{oc}}$ of $1.05 \mathrm{~V}$ were obtained after optimizing the doping density of absorber as $1 \times 10^{17} \mathrm{~cm}^{-3}$. Further optimization of defect density and thickness of absorber, PCE of $17.37 \%$, Voc of $1.17 \mathrm{~V}$, FF of $75.35 \%$ and $\mathrm{J}_{\mathrm{sc}}$ of $19.61 \mathrm{~mA} / \mathrm{cm}^{2}$ was achieved. Finally, PCE as high as $21.06 \%$, $\mathrm{J}_{\mathrm{sc}}$ of $20.08 \mathrm{~mA} / \mathrm{cm}^{2}$, FF as high as $89.45 \%$ and $\mathrm{V}_{\text {oc }}$ as high as 1.17 V were achieved upon the optimization of above-mentioned parameters. This research work analyzed the working mechanism of inverted PSC and studied the influence of key physical parameters on the performance of device. Furthermore, $\mathrm{CuI}$ is highly hydrophobic which prevent moisture to reach the absorber and from direct contact with FTO, therefore reducing charge recombination at interfaces and enhancing the performance of device. Hence, it is obviously beneficial to use CuI as HTM for the fabrication of stable, efficient and cost-effective p-i-n PSCs. These results show that inverted PSC with $\mathrm{CuI}$ as an inorganic HTM has excellent performance compared to widely used organic HTM PEDOT: PSS. CuI is cost effective showing thermal as well as moisture stability which is better alternate to PEDOT: PSS.

\section{Acknowledgement}

Authors acknowledge the funding from Higher Education Commission, Pakistan for National Research Programme for Universities (NRPU) [Project number 8545]. 


\section{Conflict of Interest}

The authors declare no conflict of interest.

\section{References}

[1] A. Kojima, K. Teshima, Y. Shirai, T. Miyasaka, Organometal Halide Perovskites as Visible-Light Sensitizers for Photovoltaic Cells, J. Am. Chem. Soc. 131 (2009) 60506051. https://doi.org/10.1021/ja809598r.

[2] S.Z. Haider, H. Anwar, M. Wang, A comprehensive device modelling of perovskite solar cell with inorganic copper iodide as hole transport material, Semicond. Sci. Technol. 33 (2018) 1-12. https://doi.org/10.1088/1361-6641/aaa596.

[3] S.Z. Haider, H. Anwar, Y. Jamil, M. Shahid, A comparative study of interface engineering with different hole transport materials for high-performance perovskite solar cells, J. Phys. Chem. Solids. 136 (2020) 1-11. https://doi.org/10.1016/j.jpcs.2019.109147.

[4] S.Z. Haider, H. Anwar, M. Wang, Theoretical Device Engineering for High-Performance Perovskite Solar Cells Using CuSCN as Hole Transport Material Boost the Efficiency Above 25\%, Phys. Status Solidi. 216 (2019) 1-12. https://doi.org/10.1002/pssa.201900102.

[5] J. Burschka, N. Pellet, S.-J. Moon, R. Humphry-Baker, P. Gao, M.K. Nazeeruddin, M. Grätzel, Sequential deposition as a route to high-performance perovskite-sensitized solar cells, Nature. 499 (2013) 316-319. https://doi.org/10.1038/nature12340.

[6] J.-H. Im, C.-R. Lee, J.-W. Lee, S.-W. Park, N.-G. Park, 6.5\% efficient perovskite quantum-dot-sensitized solar cell, Nanoscale. 3 (2011) 4088-4093. 
https://doi.org/10.1039/c1nr10867k.

[7] H.-S. Kim, C.-R. Lee, J.-H. Im, K.-B. Lee, T. Moehl, A. Marchioro, S.-J. Moon, R.

Humphry-Baker, J.-H. Yum, J.E. Moser, M. Grätzel, N.-G. Park, Lead Iodide Perovskite Sensitized All-Solid-State Submicron Thin Film Mesoscopic Solar Cell with Efficiency Exceeding 9\%, Sci. Rep. 2 (2012) 1-7. https://doi.org/10.1038/srep00591.

[8] M.M. Lee, J. Teuscher, T. Miyasaka, T.N. Murakami, H.J. Snaith, Efficient Hybrid Solar Cells Based on Meso-Superstructured Organometal Halide Perovskites, Science (80-. ). 338 (2012) 643-647. https://doi.org/10.1126/science.1228604.

[9] Q.-K. Wang, R.-B. Wang, P.-F. Shen, C. Li, Y.-Q. Li, L.-J. Liu, S. Duhm, J.-X. Tang, Energy Level Offsets at Lead Halide Perovskite/Organic Hybrid Interfaces and Their Impacts on Charge Separation, Adv. Mater. Interfaces. 2 (2015) 1-7. https://doi.org/10.1002/admi.201400528.

[10] C.D. Bailie, M.G. Christoforo, J.P. Mailoa, A.R. Bowring, E.L. Unger, W.H. Nguyen, J. Burschka, N. Pellet, J.Z. Lee, M. Grätzel, R. Noufi, T. Buonassisi, A. Salleo, M.D. McGehee, Semi-transparent perovskite solar cells for tandems with silicon and CIGS, Energy Environ. Sci. 8 (2015) 956-963. https://doi.org/10.1039/c4ee03322a.

[11] D.P. McMeekin, G. Sadoughi, W. Rehman, G.E. Eperon, M. Saliba, M.T. Hörantner, A. Haghighirad, N. Sakai, L. Korte, B. Rech, M.B. Johnston, L.M. Herz, H.J. Snaith, A mixed-cation lead mixed-halide perovskite absorber for tandem solar cells., Science. 351 (2016) 151-5. https://doi.org/10.1126/science.aad5845.

[12] J.H. Heo, H.J. Han, D. Kim, T.K. Ahn, S.H. Im, Hysteresis-less inverted CH3NH3PbI3 planar perovskite hybrid solar cells with $18.1 \%$ power conversion efficiency, Energy 
Environ. Sci. 8 (2015) 1602-1608. https://doi.org/10.1039/c5ee00120j.

[13] P. Docampo, J.M. Ball, M. Darwich, G.E. Eperon, H.J. Snaith, Efficient organometal trihalide perovskite planar-heterojunction solar cells on flexible polymer substrates, Nat. Commun. 4 (2013) 2761. https://doi.org/10.1038/ncomms3761.

[14] L.-B. Chang, C.-C. Tseng, G. Wu, W.-S. Feng, M.-J. Jeng, L.-C. Chen, K.-L. Lee, E. Popko, L. Jacak, K. Gwozdz, L.-B. Chang, C.-C. Tseng, G. Wu, W.-S. Feng, M.-J. Jeng, L.-C. Chen, K.-L. Lee, E. Popko, L. Jacak, K. Gwozdz, Low-Cost CuIn1-xGaxSe2 UltraThin Hole-Transporting Material Layer for Perovskite/CIGSe Heterojunction Solar Cells, Appl. Sci. 9 (2019) 719. https://doi.org/10.3390/app9040719.

[15] B. Xu, S.-A. Gopalan, A.-I. Gopalan, N. Muthuchamy, K.-P. Lee, J.-S. Lee, Y. Jiang, S.W. Lee, S.-W. Kim, J.-S. Kim, H.-M. Jeong, J.-B. Kwon, J.-H. Bae, S.-W. Kang, Functional solid additive modified PEDOT:PSS as an anode buffer layer for enhanced photovoltaic performance and stability in polymer solar cells., Sci. Rep. 7 (2017) 1-12. https://doi.org/10.1038/srep45079.

[16] W. Sun, S. Ye, H. Rao, Y. Li, Z. Liu, L. Xiao, Z. Chen, Z. Bian, C. Huang, L. Spiccia, L. Xiao, Z. Bian, C. Huang, Room-temperature and solution-processed copper iodide as the hole transport layer for inverted planar perovskite solar cells, Nanoscale. 8 (2016) 1595415960. https://doi.org/10.1039/C6NR04288K.

[17] E. Li, W. Li, L. Li, H. Zhang, C. Shen, Z. Wu, W. Zhang, X. Xu, H. Tian, W.H. Zhu, Y. $\mathrm{Wu}$, Efficient p-i-n structured perovskite solar cells employing low-cost and highly reproducible oligomers as hole transporting materials, Sci. China Chem. 62 (2019) 767774. https://doi.org/10.1007/s11426-018-9452-9. 
[18] B.G. Ganga, S.M. Seetharaman, P.C.R. Varma, M.A.G. Namboothiry, P.N. Santhosh, Photovoltaic properties of low temperature solution processed earth abundant $\mathrm{CuO}$ nanocrystal-based hybrid solar cells, Phys. Status Solidi. 214 (2017) 1600671. https://doi.org/10.1002/pssa.201600671.

[19] H. Fujiwara, M. Kato, M. Tamakoshi, T. Miyadera, M. Chikamatsu, Optical Characteristics and Operational Principles of Hybrid Perovskite Solar Cells (Phys. Status Solidi A 12/2018), Phys. Status Solidi. 215 (2018) 1870024. https://doi.org/10.1002/pssa.201870024.

[20] G. Niu, W. Li, J. Li, X. Liang, L. Wang, Enhancement of thermal stability for perovskite solar cells through cesium doping, RSC Adv. 7 (2017) 17473-17479. https://doi.org/10.1039/C6RA28501E.

[21] T.Y. Yang, N.J. Jeon, H.W. Shin, S.S. Shin, Y.Y. Kim, J. Seo, Achieving Long-Term Operational Stability of Perovskite Solar Cells with a Stabilized Efficiency Exceeding 20\% after 1000 h, Adv. Sci. 6 (2019). https://doi.org/10.1002/advs.201900528.

[22] M. Li, Y. Dai, W. Ma, B. Yang, Q. Chu, Review of New Technology for Preparing Crystalline Silicon Solar Cell Materials by Metallurgical Method, IOP Conf. Ser. Earth Environ. Sci. 94 (2017) 1-11. https://doi.org/10.1088/1755-1315/94/1/012016.

[23] Y. Sun, X. Fang, Z. Ma, L. Xu, Y. Lu, Q. Yu, N. Yuan, J. Ding, Enhanced UV-light stability of organometal halide perovskite solar cells with interface modification and a UV absorption layer, J. Mater. Chem. C. 5 (2017) 8682-8687. https://doi.org/10.1039/C7TC02603J.

[24] P. Zhao, Z. Liu, Z. Lin, D. Chen, J. Su, C. Zhang, J. Zhang, J. Chang, Y. Hao, Device 
simulation of inverted $\mathrm{CH} 3 \mathrm{NH} 3 \mathrm{PbI} 3-\mathrm{x} \mathrm{Cl}$ x perovskite solar cells based on PCBM electron transport layer and $\mathrm{NiO}$ hole transport layer, Sol. Energy. 169 (2018) 11-18. https://doi.org/10.1016/j.solener.2018.04.027.

[25] M.S. Rahman, S. Miah, M.S.W. Marma, T. Sabrina, Simulation based Investigation of Inverted Planar Perovskite Solar Cell with All Metal Oxide Inorganic Transport Layers, 2nd Int. Conf. Electr. Comput. Commun. Eng. ECCE 2019. (2019) 1-6. https://doi.org/10.1109/ECACE.2019.8679283.

[26] A. Sahu, A. Dixit, Inverted structure perovskite solar cells: A theoretical study, Curr. Appl. Phys. 18 (2018) 1583-1591. https://doi.org/10.1016/j.cap.2018.10.008.

[27] M. Goudarzi, M. Banihashemi, Simulation of an inverted perovskite solar cell with inorganic electron and hole transfer layers (Erratum), J. Photonics Energy. 7 (2017) 029901. https://doi.org/10.1117/1.jpe.7.029901.

[28] J. Gong, S. Krishnan, Simulation of inverted perovskite solar cells, in: ASME 2018 12th Int. Conf. Energy Sustain. ES 2018, Collocated with ASME 2018 Power Conf. ASME 2018 Nucl. Forum, American Society of Mechanical Engineers, 2018: pp. 1-7. https://doi.org/10.1115/ES2018-7227.

[29] Q. Fu, X. Tang, B. Huang, T. Hu, L. Tan, L. Chen, Y. Chen, Recent Progress on the LongTerm Stability of Perovskite Solar Cells, Adv. Sci. 5 (2018) 1-17. https://doi.org/10.1002/advs.201700387.

[30] A. Annadi, N. Zhang, D.B.K. Lim, H. Gong, Hole Transport Modulations in Low Dimensional $\gamma$-CuI Films: Implication for High Figure of Merit and Thin Film Transistors, ACS Appl. Electron. Mater. 1 (2019) 1029-1037. 
https://doi.org/10.1021/acsaelm.9b00177.

[31] P.M. Sirimanne, M. Rusop, T. Shirata, T. Soga, T. Jimbo, Characterization of transparent conducting $\mathrm{CuI}$ thin films prepared by pulsed laser deposition technique, Chem. Phys. Lett. 366 (2002) 485-489. https://doi.org/10.1016/S0009-2614(02)01590-7.

[32] O. Madelung, I-VII compounds, in: Semicond. Data Handb., Springer Berlin Heidelberg, Berlin, Heidelberg, 2004: pp. 245-274. https://doi.org/10.1007/978-3-642-18865-7_5.

[33] C.C. Homes, Optical Response of High-Dielectric-Constant Perovskite-Related Oxide, Science (80-. ). 293 (2001) 673-676. https://doi.org/10.1126/science.1061655.

[34] S. Torabi, F. Jahani, I. Van Severen, C. Kanimozhi, S. Patil, R.W.A. Havenith, R.C. Chiechi, L. Lutsen, D.J.M. Vanderzande, T.J. Cleij, J.C. Hummelen, L.J.A. Koster, Strategy for enhancing the dielectric constant of organic semiconductors without sacrificing charge carrier mobility and solubility, Adv. Funct. Mater. 25 (2015) 150-157. https://doi.org/10.1002/adfm.201402244.

[35] Z. El Jouad, M. Morsli, G. Louarn, L. Cattin, M. Addou, J.C. Bernède, Improving the efficiency of subphthalocyanine based planar organic solar cells through the use of MoO3/CuI double anode buffer layer, Sol. Energy Mater. Sol. Cells. 141 (2015) 429-435. https://doi.org/10.1016/j.solmat.2015.06.017.

[36] G. Zuo, Z. Li, O. Andersson, H. Abdalla, E. Wang, M. Kemerink, Molecular Doping and Trap Filling in Organic Semiconductor Host-Guest Systems, J. Phys. Chem. C. 121 (2017) 7767-7775. https://doi.org/10.1021/acs.jpcc.7b01758.

[37] M.I. Hossain, F.H. Alharbi, N. Tabet, Copper oxide as inorganic hole transport material 
for lead halide perovskite based solar cells, Sol. Energy. 120 (2015) 370-380. https://doi.org/10.1016/j.solener.2015.07.040.

[38] H. Wang, Y. Liu, M. Li, H. Huang, H.M. Xu, R.J. Hong, H. Shen, Multifunctional TiO2 nanowires-modified nanoparticles bilayer film for 3D dye-sensitized solar cells, Optoelectron. Adv. Mater. Rapid Commun. 4 (2010) 1166-1169. https://doi.org/10.1039/b000000x.

[39] C. Motta, F. El-Mellouhi, S. Sanvito, Charge carrier mobility in hybrid halide perovskites, Sci. Rep. 5 (2015) 12746. https://doi.org/10.1038/srep12746.

[40] P.W.M. Blom, J.C. Hummelen, R.A.J. Janssen, M.M. Wienk, J.M. Kroon, V.D. Mihailetchi, J.K.J. van Duren, W.J.H. Verhees, M.T. Rispens, Electron Transport in a Methanofullerene, Adv. Funct. Mater. 13 (2003) 43-46. https://doi.org/10.1002/adfm.200390004.

[41] S.J. Fonash, S.J. Fonash, Chapter Two - Material Properties and Device Physics Basic to Photovoltaics, in: Sol. Cell Device Phys., 2010: pp. 9-65. https://doi.org/10.1016/B978-012-374774-7.00002-9.

[42] G. Giorgi, J.I. Fujisawa, H. Segawa, K. Yamashita, Small photocarrier effective masses featuring ambipolar transport in methylammonium lead iodide perovskite: A density functional analysis, J. Phys. Chem. Lett. 4 (2013) 4213-4216. https://doi.org/10.1021/jz4023865.

[43] U. Mandadapu, S.V. Vedanayakam, K. Thyagarajan, Numerical Simulation of Ch $3 \mathrm{Nh} 3$ PbI 3-X Cl x Perovskite solar cell using SCAPS-1D, Int. J. Eng. Sci. Invent. 2319 (2017) 40-45. www.ijesi.org (accessed January 20, 2019). 
[44] C. Yang, M. Kneiß, F.-L. Schein, M. Lorenz, M. Grundmann, Room-temperature Domain-epitaxy of Copper Iodide Thin Films for Transparent CuI/ZnO Heterojunctions with High Rectification Ratios Larger than 109, Sci. Rep. 6 (2016) 1-8. https://doi.org/10.1038/srep21937.

[45] L. Calió, S. Kazim, M. Grätzel, S. Ahmad, Hole-Transport Materials for Perovskite Solar Cells, Angew. Chemie - Int. Ed. 55 (2016) 14522-14545. https://doi.org/10.1002/anie.201601757.

[46] S.H. Yoo, J.M. Kum, S.O. Cho, Tuning the electronic band structure of PCBM by electron irradiation, Nanoscale Res. Lett. 6 (2011) 1-7. https://doi.org/10.1186/1556-276X-6-545.

[47] U. Mandadapu, S.V. Vedanayakam, K. Thyagarajan, M.R. Reddy, B.J. Babu, Design and simulation of high efficiency tin halide perovskite solar cell, Int. J. Renew. Energy Res. 7 (2017).

[48] J. Liu, Y. Zhang, C. Liu, M. Peng, A. Yu, J. Kou, W. Liu, J. Zhai, J. Liu, Piezophototronic effect enhanced UV photodetector based on $\mathrm{CuI} / \mathrm{ZnO}$ double-shell grown on flexible copper microwire, Nanoscale Res. Lett. 11 (2016) 281. https://doi.org/10.1186/s11671-016-1499-1.

[49] J. Jeng, Y. Chiang, M. Lee, T. Guo, P. Chen, T. Wen, Methylammonium lead iodide perovskite/fullerene-based hybrid solar cells, SPIE Newsroom. (2013) 3-6. https://doi.org/10.1117/2.1201307.005033.

[50] B.W. Larson, J.B. Whitaker, X. Bin Wang, A.A. Popov, G. Rumbles, N. Kopidakis, S.H. Strauss, O. V. Boltalina, Electron affinity of Phenyl-C61-butyric acid methyl ester (PCBM), J. Phys. Chem. C. 117 (2013) 14958-14964. https://doi.org/10.1021/jp403312g. 
[51] H. Wang, Z. Yu, X. Jiang, J. Li, B. Cai, X. Yang, L. Sun, Efficient and Stable Inverted Planar Perovskite Solar Cells Employing CuI as Hole-Transporting Layer Prepared by Solid-Gas Transformation, Energy Technol. 5 (2017) 1836-1843. https://doi.org/10.1002/ente.201700422.

[52] W.-Y. Chen, L.-L. Deng, S.-M. Dai, X. Wang, C.-B. Tian, X.-X. Zhan, S.-Y. Xie, R.-B. Huang, L.-S. Zheng, Low-cost solution-processed copper iodide as an alternative to PEDOT:PSS hole transport layer for efficient and stable inverted planar heterojunction perovskite solar cells, J. Mater. Chem. A. 3 (2015) 19353-19359. https://doi.org/10.1039/C5TA05286F.

[53] O. Malinkiewicz, A. Yella, Y.H. Lee, G.M. Espallargas, M. Graetzel, M.K. Nazeeruddin, H.J. Bolink, Perovskite solar cells employing organic charge-transport layers, Nat. Photonics 2013 82. 8 (2013) 128. https://doi.org/10.1038/nphoton.2013.341.

[54] L.A. Frolova, N.N. Dremova, P.A. Troshin, The chemical origin of the p-type and n-type doping effects in the hybrid methylammonium-lead iodide (MAPbI 3 ) perovskite solar cells, Chem. Commun. 51 (2015) 14917-14920. https://doi.org/10.1039/C5CC05205J.

[55] P. Cui, D. Wei, J. Ji, H. Huang, E. Jia, S. Dou, T. Wang, W. Wang, M. Li, Planar p-n homojunction perovskite solar cells with efficiency exceeding 21.3\%, Nat. Energy. 4 (2019) 150-159. https://doi.org/10.1038/s41560-018-0324-8.

[56] G.D. Tainter, M.T. Hörantner, L.M. Pazos-Outón, R.D. Lamboll, H. Āboliņ̧̌̌, T. Leijtens, S. Mahesh, R.H. Friend, H.J. Snaith, H.J. Joyce, F. Deschler, Long-Range Charge Extraction in Back-Contact Perovskite Architectures via Suppressed Recombination, Joule. 3 (2019) 1301-1313. https://doi.org/10.1016/j.joule.2019.03.010. 
[57] H. Kim, K.-G. Lim, T.-W. Lee, Planar heterojunction organometal halide perovskite solar cells: roles of interfacial layers, Energy Environ. Sci. 9 (2016) 12-30. https://doi.org/10.1039/C5EE02194D.

[58] M.R. Ahmadian-Yazdi, F. Zabihi, M. Habibi, M. Eslamian, Effects of Process Parameters on the Characteristics of Mixed-Halide Perovskite Solar Cells Fabricated by One-Step and Two-Step Sequential Coating, Nanoscale Res. Lett. 11 (2016) 408. https://doi.org/10.1186/s11671-016-1601-8.

[59] J. Barbé, M.L. Tietze, M. Neophytou, B. Murali, E. Alarousu, A. El Labban, M. Abulikemu, W. Yue, O.F. Mohammed, I. McCulloch, A. Amassian, S. Del Gobbo, Amorphous Tin Oxide as a Low-Temperature-Processed Electron-Transport Layer for Organic and Hybrid Perovskite Solar Cells, ACS Appl. Mater. Interfaces. 9 (2017) 1182811836. https://doi.org/10.1021/acsami.6b13675.

[60] H. Wang, Z. Yu, J. Lai, X. Song, X. Yang, A. Hagfeldt, L. Sun, One plus one greater than two: high-performance inverted planar perovskite solar cells based on a composite CuI/CuSCN hole-transporting layer, J. Mater. Chem. A. 6 (2018) 21435-21444. https://doi.org/10.1039/C8TA07332E.

[61] W. Sun, S. Ye, H. Rao, Y. Li, Z. Liu, L. Xiao, Z. Chen, Z. Bian, C. Huang, Roomtemperature and solution-processed copper iodide as the hole transport layer for inverted planar perovskite solar cells, Nanoscale. 8 (2016) 15954-15960. https://doi.org/10.1039/c6nr04288k.

[62] J. Cao, B. Wu, J. Peng, X. Feng, C. Li, Y. Tang, Copper-copper iodide hybrid nanostructure as hole transport material for efficient and stable inverted perovskite solar 
cells, Sci. China Chem. 62 (2019) 363-369. https://doi.org/10.1007/s11426-018-9386-5.

\section{Graphical abstract}
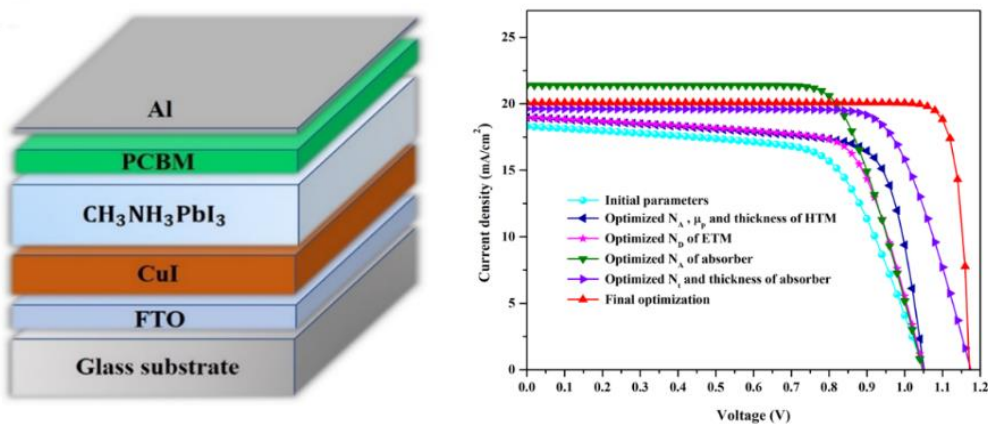